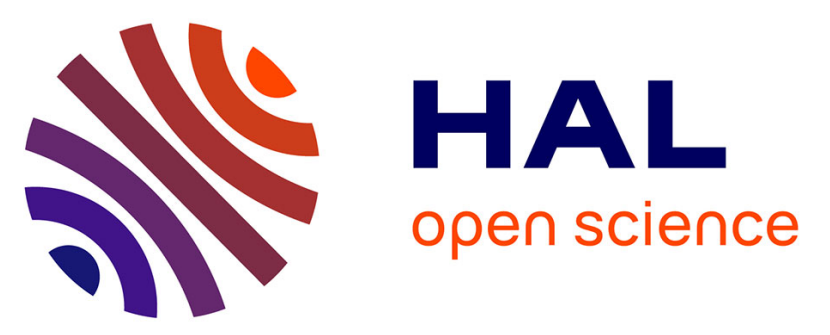

\title{
The maternal microbiota influences the post-natal development of gut barrier function and immune system in piglets and their gut adaptation to a high fat diet later in life.
}

Gaëlle Boudry, Stéphanie Ferret-Bernard, Gerard Savary, Laurence Le Normand, Cécile Perrier, Odette Perez-Gutteriez, Jing Zhang, Hauke Smidt, Isabelle Luron

\section{- To cite this version:}

Gaëlle Boudry, Stéphanie Ferret-Bernard, Gerard Savary, Laurence Le Normand, Cécile Perrier, et al.. The maternal microbiota influences the post-natal development of gut barrier function and immune system in piglets and their gut adaptation to a high fat diet later in life.. Digestive Disease Week, May 2012, San Diego, United States. Gastroenterology Vol. 142, Issue 5, Supplement 1, Page S-14. hal-01210340

\author{
HAL Id: hal-01210340 \\ https://hal.science/hal-01210340
}

Submitted on 3 Jun 2020

HAL is a multi-disciplinary open access archive for the deposit and dissemination of scientific research documents, whether they are published or not. The documents may come from teaching and research institutions in France or abroad, or from public or private research centers.
L'archive ouverte pluridisciplinaire HAL, est destinée au dépôt et à la diffusion de documents scientifiques de niveau recherche, publiés ou non, émanant des établissements d'enseignement et de recherche français ou étrangers, des laboratoires publics ou privés. 
The maternal microbiota influences the post-natal development of gut barrier function and immune system in piglets and their gut adaptation to a high fat diet later in life.

Gaëlle BOUDRY ${ }^{1}$, Stéphanie FERRET-BERNARD ${ }^{1}$, Gérard SAVARY ${ }^{1}$, Laurence LE NORMAND ${ }^{1}$, Cecile PERRIER ${ }^{1}$, Odette PEREZ-GUTTERIEZ ${ }^{2}$, Jing ZHANG $^{2}$, Hauke SMIDT ${ }^{2}$, Isabelle LE HUEROU-LURON ${ }^{1}$

1 INRA, UR1341 ADNC, St-Gilles, FRANCE, ${ }^{2}$ Laboratory of Microbiology, Wageningen University, THE NETHERLANDS

Background: The microbiota drives many intestinal functions. Its early-life acquisition greatly depends on the maternal microbiota. Its composition is strongly affected by a high fat (HF) diet, leading to gut barrier defects, increased LPS passage and development of metabolic inflammation. Our aim was to investigate gut barrier function and GALT response to LPS in piglets deriving from sows whose microbiota was manipulated by antibiotics. Long-term consequences on gut adaptation to a HF diet were examined in adult offspring. Methods: Sows were given amoxicillin ( $40 \mathrm{mg} / \mathrm{kg} / \mathrm{d}$ ) per os (ATBQ, $\mathrm{n}=11 \mathrm{vs}$. CTRL, $\mathrm{n}=12$ ) from 10 days before to 21 days after parturition. One piglet per litter was sacrificed at post-natal day (PND) 14, 21 and 28. The remaining piglets were weaned at PND28 and given either a low fat (LF) or a HF diet from PND150 to 180. Results: Microbiota composition profiling using a comprehensive $16 \mathrm{~S}$ ribosomal RNA gene-targeted microarray revealed that sow fecal microbiota was modified by the ATBQ treatment (multivariate analysis indicated significant decrease in lactobacilli species and increase in Bacteroidetes, $\mathrm{P}<0.05)$. At PND14, ileal permeability was greater in ATBQ than CTRL piglets (FITC-dextran 4000 flux in Ussing chambers: $+71 \%, P<0.05$ ). Its cholinergic regulation was altered (increase in permeability with carbachol in CTRL only $(+28 \%, P<0.05)$, mucosal acetylcholine concentration: $+48 \%$ in ATBQ vs. CTRL, $P<0.05)$. At PND21, no increase in proliferation of LPMCs in response to LPS was noticed, demonstrating LPMC tolerance to LPS in both groups. However, while LPMC of CTRL piglets did not secrete TNFa in response to LPS, those of ATBQ piglets did. At PND180, no difference in ileal permeability was observed between CTRL and ATBQ pigs fed the LF diet. However, while ileal permeability was increased in HF-fed CTRL pigs compared to LF-fed ones $(+46 \%, P<0.05)$, no such increase was observed in ATBQ animals. Moreover, while ileal permeability was increased by carbachol in LF-fed CTRL pigs $(+30 \%, P<0.05)$, no increase was observed in HF-fed CTRL pigs nor in LF-or HF-fed ATBQ pigs. At the GALT level, LPMC proliferative response to LPS tended to be higher in CTRL vs. ATBQ pigs $(p<0.1)$, irrespective of their diet. Secretion of TNFa by ileal explants stimulated by pokeweed mitogen was blunted in ATBQ pigs compared to CTRL ones, irrespective of the diet $(-57 \% \mathrm{P}<0.05)$. Moreover, TNF $\alpha$ secretion by ileal explants was not increased in response to LPS in HF-fed ATBQ pigs as opposed to LF-fed ATBQ pigs or LF-and HF-fed CTRL pigs $(+24 \%,+50 \%$ and $+48 \%$ respectively, $\mathrm{P}<0.05)$. Conclusion: Manipulating the maternal microbiota modified both ileal barrier function and GALT response to LPS during the neonatal period. It also deeply influenced the intestinal adaptive response to a HF diet in adult offspring, suggesting a microbiota imprinting in gut response to a HF diet. 